\title{
Multiple sulphur and iron isotope composition of detrital pyrite in Archaean sedimentary rocks: a new tool for provenance analysis
}

\author{
Axel Hofmann ${ }^{1}$, Andrey Bekker ${ }^{2,3}$, Olivier Rouxel ${ }^{4}$, Doug Rumble ${ }^{3}$ and Sharad Master ${ }^{5}$ \\ ${ }^{1}$ School of Geological Sciences, University of KwaZulu-Natal, Durban, South Africa; \\ hofmann@ukzn.ac.za \\ ${ }^{2}$ Department of Geological Sciences, University of Manitoba, Winnipeg, Manitoba, R3T 2N2 \\ Canada \\ ${ }^{3}$ Geophysical Laboratory, Carnegie Institution, Washington, DC, 20015 USA \\ ${ }^{4}$ Marine Chemistry and Geochemistry Department, Woods Hole Oceanographic Institution, \\ Woods Hole, MA 02543, USA \\ ${ }^{5}$ Economic Geology Research Institute, School of Geosciences, University of the \\ Witwatersrand, Wits 2050, Johannesburg, South Africa
}

\begin{abstract}
Multiple $\mathrm{S}\left(\delta^{34} \mathrm{~S}\right.$ and $\left.\delta^{33} \mathrm{~S}\right)$ and $\mathrm{Fe}\left(\delta^{56} \mathrm{Fe}\right)$ isotope analyses of rounded pyrite grains from 3.1 to $2.6 \mathrm{Ga}$ conglomerates of southern Africa indicate their detrital origin, which supports anoxic surface conditions in the Archaean. Rounded pyrites from Meso- to Neoarchaean gold and uranium-bearing strata of South Africa are derived from both crustal and sedimentary sources, the latter being characterised by non-mass dependent fractionation of $\mathrm{S}$ isotopes $\left(\Delta^{33} \mathrm{~S}\right.$ as negative as $-1.35 \%$ ) and large range of $\mathrm{Fe}$ isotope values $\left(\delta^{56} \mathrm{Fe}\right.$ between -1.1 and $1.2 \%$ ). Most sediment-sourced pyrite grains are likely derived from sulphide nodules in marine organic matter-rich shales, sedimentary exhalites and volcanogenic massive sulphide deposits. Some sedimentary pyrite grains may have been derived from in situ sulphidised Feoxides, prior to their incorporation into the conglomerates, as indicated by unusually high positive $\delta^{56} \mathrm{Fe}$ values. Sedimentary sulphides without significant non-mass dependent fractionation of $\mathrm{S}$ isotopes were also present in the source of some conglomerates. The abundance in these rocks of detrital pyrite unstable in the oxygenated atmosphere may suggest factors other than high $p \mathrm{O}_{2}$ as the cause for the absence of significant non-mass dependent fractionation processes in the $3.2-2.7 \mathrm{Ga}$ atmosphere. Rounded pyrites from the ca. $2.6 \mathrm{Ga}$ conglomerates of the Belingwe greenstone belt in Zimbabwe have strongly fractionated $\delta^{34} \mathrm{~S}$, $\Delta^{33} \mathrm{~S}$ and $\delta^{56} \mathrm{Fe}$ values, the source of which can be traced back to black shale-hosted massive
\end{abstract}


sulphides in the underlying strata. The study demonstrates the utility of combined multiple $\mathrm{S}$ and $\mathrm{Fe}$ isotope analysis for provenance reconstruction of Archaean sedimentary successions.

Keywords: Archaean; Witwatersrand basin; Belingwe greenstone belt; S isotope; Fe isotope; pyrite; gold mineralisation

\section{Introduction}

Rounded grains of pyrite are a common component of conglomerate-hosted gold and uranium deposits of the Mesoarchaean Witwatersrand basin of South Africa. Supporters of the placer model for these deposits have long argued for a detrital origin of these grains (Hallbauer, 1986; Minter, 2006). If correct, their abundance and association with detrital uraninite indicates low oxygen levels in the Archaean atmosphere (Holland, 1984; Rasmussen and Buick, 1999), as pyrite and uraninite are unstable in modern surface environments (Krupp et al., 1994). Different sources for detrital pyrite have been discussed, including sedimentary, igneous, and various hydrothermal sources (Barton and Hallbauer, 1996; England, 2002), while the source of gold remains poorly constrained in this model (Robb and Meyer, 1990; Frimmel, 2008). The placer model has been challenged by several workers who ascribe these grains to post-depositional pyritisation of non-sulphidic (e.g. Fe-oxide) detrital grains during hydrothermal alteration (e.g. Barnicoat et al., 1997; Phillips and Law, 2000). These workers also regard the gold to be entirely secondary and argue that rounded pyrites cannot be used to support the model of a reducing Archean atmosphere (Law and Phillips, 2006). Evidence for gold remobilization preserved in the gold-bearing conglomerates has resulted in the development of a modified theory by the "placerists", in which pyrite, uraninite and gold are regarded as detrital grains that were affected by recrystallisation and short-distance remobilisation during metamorphism, hydrothermal alteration, and hydrocarbon migration. The controversy on the origin of the pyrite and gold has been raging for more than a century and the stakes are high, as $40 \%$ of all the gold ever mined is derived from the Witwatersrand basin (Frimmel, 2005).

We have carried out multiple $\mathrm{S}\left(\delta^{34} \mathrm{~S}\right.$ and $\left.\delta^{33} \mathrm{~S}\right)$ and $\mathrm{Fe}\left(\delta^{56} \mathrm{Fe}\right)$ isotope analysis of rounded pyrite grains from Archaean conglomerates in order to identify their origin and, if detrital, their provenance. Non-mass dependent fractionation (NMDF) of $\mathrm{S}$ isotopes is caused by $\mathrm{SO}_{2}$ photolysis under ultraviolet radiation (Farquhar et al., 2001). Although thermochemical sulphate reduction in the presence of amino acids could generate NMDF of S isotopes (Watanabe et al., 2009), it has not yet been demonstrated that this process can account for the 
full range of NMDF observed in Archaean and early Palaeoproterozoic sediments nor that it is applicable to a diverse range of geological environments on the early Earth. NMDF of S isotopes is defined as $\Delta^{33} \mathrm{~S} \approx \delta^{33} \mathrm{~S}^{*}-0.515^{*} \delta^{34} \mathrm{~S}^{*}$, where $\delta^{33} \mathrm{~S}^{*}$ and $\delta^{34} \mathrm{~S}^{*}$ are derived from conventional $\delta$ notations with respect to $\operatorname{VCDT}$ as $\delta^{3 \mathrm{x}} \mathrm{S}^{*}=1,000 \ln \left(\left[\delta^{3 \mathrm{x}} \mathrm{S} / 1,000\right]+1\right)$ (Hulston and Thode, 1965; Bekker et al., 2004). NMDF in Archaean sulphides and sulphates has been attributed to the absence of an ozone shield in the anoxic Archaean atmosphere (Farquhar et al., 2000; Pavlov and Kasting, 2002). Multiple S isotope analysis thus allows to distinguish between $S$ that passed through the Archaean atmosphere $\left(\Delta^{33} S \neq 0 \%\right)$ and magmatic $S$ incorporated into hydrothermal fluids $\left(\Delta^{33} \mathrm{~S}=0 \%\right.$ ). Sulphides present in volcanogenic massive sulphide (VMS) deposits and banded iron formations (BIFs) that formed by seawater circulation through hydrothermal systems and seawater sulphate reduction commonly carry near to zero or small negative $\Delta^{33} \mathrm{~S}$ values (Farquhar and Wing, 2005; Jamieson et al, 2006; Ueno et al., 2008). In contrast, disseminated sulphides in Archaean black shales that formed away from hydrothermal circulation have mostly positive $\Delta^{33} \mathrm{~S}$ values inherited from photochemically-produced reduced S species such as elemental S (Farquhar and Wing, 2003, 2005; Ono et al., 2009). Pyrite nodules in Archaean organic matter-rich shales have mostly negative $\Delta^{33} \mathrm{~S}$ values and might reflect seawater sulphate reduction in sediments during diagenesis (Bekker et al., 2008a; Ono et al., 2009).

Fe isotope fractionation occurs during redox changes, fluid-mineral interactions and biological processes (see Dauphas and Rouxel, 2006, Anbar and Rouxel, 2007, and Johnson et al., 2008 for recent reviews). While igneous rocks and siliciclastic sedimentary rocks with low carbon and sulphur contents have limited Fe isotope variations, diagenetic pyrites in Archaean black shales show highly variable and mostly negative values ranging from -3.5 to +0.5 \%o (Rouxel et al., 2005; Yamaguchi et al., 2005; Archer and Vance, 2006). The same applies to bulk composition of C- and S-rich shales (Yamaguchi et al., 2005). The c. 2.96 and $2.90 \mathrm{Ga}$ magnetite-rich shales of the Witwatersrand Supergroup have also yielded predominantly negative $\delta^{56} \mathrm{Fe}$ values (-1.4 to $0.3 \%$; Yamaguchi et al., 2005). In contrast, Feoxides in Archaean BIFs are frequently characterised by positive $\delta^{56} \mathrm{Fe}$ values up to $1.6 \%$ (Johnson et al., 2003; Dauphas et al., 2004; Rouxel et al., 2005; Whitehouse and Fedo, 2007), although $\delta^{56} \mathrm{Fe}$ values for magnetite-rich bands from the c. 2.48-2.45 Ga Hamersley and Transvaal BIFs of Western Australia and South Africa, respectively, range from $-1.0 \%$ to $+1.2 \%$, with the average of $0.0 \%$ (Johnson et al., 2008). Modern seafloor hydrothermal pyrite deposits have variable but mostly negative $\delta^{56} \mathrm{Fe}$ values ranging from -2.1 to $-0.1 \%$, a 
wider range than that of seafloor-hydrothermal fluids defined at around $-0.5 \pm 0.3 \%$ (Rouxel et al., 2004, 2008a; Sharma et al., 2001; Beard et al., 2003) and, likely, reflecting variable kinetic and/or equilibrium isotope effect during pyrite precipitation pathways in hydrothermal conditions (Rouxel et al., 2008a). In general, Precambrian VMS deposits are characterized by pyrite having similar range of $\delta^{56} \mathrm{Fe}$ values, between -2.4 and $0.0 \%$ consistent with putative hydrothermal fluid values and aforementioned kinetic effects (Rouxel, unpubl. data; Bekker et al., submitted).

Here, we report multiple sulphur and iron isotope values of rounded pyrite grains that are consistent with their detrital origin. Our data distinguish igneous, hydrothermal, and various sedimentary sources and shed light on the provenance of Witwatersrand-type gold and uranium placer deposits.

\section{Sample localities and mineralogy}

Southern Africa is known for some of the best preserved sedimentary successions of Archaean age, which include Palaeo- to Neoarchaean volcano-sedimentary greenstone sequences and cratonic cover successions of the Kaapvaal and Zimbabwe cratons (Fig. 1). We have carried out isotope analysis of pyrite grains from Archaean conglomerates, ranging in age from 3.08 to $2.60 \mathrm{Ga}$ (Table 1). In the Cheshire Formation, the youngest stratigraphic unit of the Belingwe greenstone belt in Zimbabwe, pyrite is present as subangular to well-rounded, sand- to fine pebble-sized grains (Fig. 2a) that form a minor constituent of basalt pebble conglomerates and grits. Rounded pyrite in Archaean strata of South Africa (Fig. 2b-f) is associated with quartz and chert pebble conglomerates and grits that were deposited in fluvial and shallow-marine environments on the Kaapvaal craton. Extensive gold and uranium mineralisation is associated with these conglomerates, also known as reefs in South Africa.

The investigated samples contain pyrite of three main types (Table 1): rounded massive pyrite, rounded porous pyrite, and authigenic pyrite, in accordance with previous observations from the same reef horizons (Ramdohr, 1958; Saager, 1970; Feather and Koen, 1975; Utter, 1978; Hallbauer, 1986; England et al., 2002). Rounded grains are spherical to discoidal, up to $1 \mathrm{~cm}$ in diameter and include massive and, less commonly, porous varieties, the latter with inclusions of various silicate minerals, such as quartz and phyllosilicates (Fig. 2b-f). Many porous grains consist of micron-sized pyrite crystals (aggregate pyrite of England et al., 2002) and have a very fine, microporous texture. Porous grains with planar laminations, concentric laminations, or radial textures were observed in several samples. These textures are commonly truncated at the grain margin, which is strong evidence for a detrital origin of these 
grains (Fig. 2d-e). Grains containing domains of massive and porous pyrite also occur, with the massive pyrite either forming discrete layers or filling secondary fractures (Fig. 2d-f). An authigenic variety of euhedral and subhedral, commonly cube-shaped massive pyrite is present in several samples, especially in those from the Ventersdorp Contact Reef. Rounded, massive, and, to a lesser degree, rounded, porous pyrite varieties were investigated in this study. A few cubic grains were also analysed for comparison (Table S1).

\section{Analytical procedures}

Pyrite granules and pebbles were drilled with a diamond coring device from cut samples and crushed to micron-sized particles. In a few cases where pyrite grains were too small for drilling, samples were dissolved in HF to obtain pure pyrite separates (see Table S1). Pyrite fragments were hand-picked under a binocular microscope and the texture of the selected grains was determined.

Sulphur isotope ratios of pyrite separates (one grain was converted to $\mathrm{Ag}_{2} \mathrm{~S}$ prior to analysis) were determined at the Geophysical Laboratory, using techniques described by $\mathrm{Hu}$ et al. (2003). Approximately 0.5 to $1 \mathrm{mg}$ of pyrite separate (or 1 to $2 \mathrm{mg}$ of $\mathrm{Ag}_{2} \mathrm{~S}$ ) was reacted with fluorine at 25-30 torr with the assistance of a $25 \mathrm{~W} \mathrm{CO}$ infrared laser in a vacuum chamber. The produced $\mathrm{SF}_{6}$ was purified by dual gas chromatography before being introduced into a Thermo Scientific MAT 253 mass-spectrometer for multiple sulphur isotope measurements in a dual-inlet mode (Ono et al., 2006a). The sulphur isotope compositions are reported with respect to VCDT. The intralaboratory precision for $\delta^{34} \mathrm{~S}, \delta^{33} \mathrm{~S}$, and $\Delta^{33} \mathrm{~S}$ values based on multiple $\mathrm{S}$ isotope analysis of CDT material and internal laboratory standards (Maine Light and Alpha Aesar pyrite) is better than 0.34, 0.19, and $0.03 \%$, respectively.

For $\mathrm{Fe}$ isotope analysis, sulphide mineral separates were dissolved in $\mathrm{HNO}_{3}-\mathrm{HCl}$ acid mixture. For several large pyrite grains from the Mozaan Contact Reef we analysed handpicked pyrite fragments as well as the bulk pyrite sample. Fe was purified on Bio-Rad AG1X8 anion resin and iron isotope ratios were determined with a Thermo Scientific Neptune multicollector inductively coupled plasma mass-spectrometer (MC-ICP-MS) following previously published methods (Rouxel et al., 2005, 2008a, 2008b). Fe isotope values are reported relative to the Fe-isotope standard IRMM-14 using the conventional delta notations. Based on duplicated chemical purification and isotope analysis of reference materials, the long term external reproducibility is about $0.08 \%$ for $\delta^{56} \mathrm{Fe}$ values ( 2 standard deviations). Trace and major element concentrations in pyrite separates were determined for the same aliquot that was used for Fe-isotope analysis. After a $10^{5}$-fold dilution of the sample, major 
and trace metal compositions were determined by high-resolution ICP-MS (Thermo Scientific Element II) using a quartz spray chamber. Instrumental sensitivity and matrix effects are corrected using an Indium internal standard and through standardization to matrix-matched multi-element solutions.

\section{Results}

\subsection{Belingwe greenstone belt, Zimbabwe}

The Ngezi Group of the Belingwe greenstone belt consists of three main stratigraphic units (Hofmann and Kusky, 2004). The c. 2.7 Ga Manjeri Formation is a $\leq 250 \mathrm{~m}$ thick, deepeningupward sedimentary sequence that consists of fluvial to shallow-marine clastic and chemical sedimentary rocks that are capped by a $5-10 \mathrm{~m}$ thick horizon of carbonaceous shale, chert and massive sulphide (Jimmy Member). The Manjeri Formation is structurally overlain by a submarine lava plain sequence of komatiites and basalts (Reliance and Zeederbergs formations). The uppermost c. $2.6 \mathrm{Ga}$ Cheshire Formation is a sedimentary foreland basin sequence that consists predominantly of marine turbidite deposits. Rounded pyrite grains are common in basalt pebble conglomerates and sandstones throughout the Cheshire Formation and form up to $10 \mathrm{vol.} \%$ of the detrital component. Sedimentary sulphide in carbonaceous shale at the base of the Cheshire Formation is present locally, such as at the defunct Agincourt gold mine (Hofmann et al., 2001). Provenance modelling has shown that the Cheshire Formation is derived predominantly from erosion of strata compositionally identical to the Reliance and Zeederbergs formations (Hofmann et al., 2003). To establish the source of rounded pyrite grains in the Cheshire Formation, we have analysed several of these grains, pyrite layers and veins in carbonaceous shale from the Agincourt Mine as well as massive pyrite from the underlying Manjeri Formation (Table S1, Fig. 3a). Rounded pyrites from the Cheshire Formation show a large spread in $\delta^{34} \mathrm{~S}$ values (-17.3 to $9.2 \%$ ) and have consistently negative $\Delta^{33} \mathrm{~S}$ values (-0.94 to $-0.22 \%$ ). Values of $\delta^{56} \mathrm{Fe}$ are also highly negative (-3.6 to -1.8 $\%$; Fig. 4). Pyrite in the Cheshire shale is isotopically distinct, with $\delta^{34} \mathrm{~S}$ values of $0.2-3.5 \%$ and $\Delta^{33} \mathrm{~S}$ of 0.38 to $1.96 \%$. Massive sulphides from the Manjeri Formation have very similar $\delta^{34} \mathrm{~S}, \Delta^{33} \mathrm{~S}$ and $\delta^{56} \mathrm{Fe}$ values with those of the rounded pyrite grains (Table S1, Fig. 3a and 4). The trace element composition (Table S1) of Cheshire rounded pyrite and Manjeri massive pyrite is broadly similar (low As $(<200 \mathrm{ppm}), \mathrm{Au}(<2.3 \mathrm{ppm})$, and $\mathrm{U}(<0.4 \mathrm{ppm})$; high $\mathrm{Mn}$ (>90 ppm); $\mathrm{Co} / \mathrm{Ni} \approx 1$; Fig. 5), except for base metals $(\mathrm{Cu}, \mathrm{Zn}, \mathrm{Pb}$, and $\mathrm{Ni}$ ) that have higher concentrations in the Cheshire pyrite. 


\subsection{Archaean intracratonic basin deposits, South Africa}

The c. 3.08 Ga (Armstrong et al, 1991; Robb et al., 1992) Dominion Reef at the base of the intracratonic rift sequence of the Dominion Group is a conglomerate bed that rests on granitoid basement rocks and is overlain by amygdaloidal lava. The reef is rich in pyrite and uraninite (Hiemstra, 1968), but low in gold content and has been mainly mined for uranium. Rounded, massive pyrite has a moderate range of $\delta^{34} \mathrm{~S}$ values $(-1.0$ to $7.6 \%$; Fig. $3 \mathrm{~b}), \Delta^{33} \mathrm{~S}$ values close to $0.0 \%$, except for one grain yielding $0.15 \%$, and a $\delta^{56} \mathrm{Fe}$ value of $0.36 \%$, slightly more positive than crustal $\delta^{56} \mathrm{Fe}$ value defined at $\sim 0.09 \%$. Intergrown chalcopyrite and pyrite from a quartz vein in the underlying basement granite and cubic pyrite in the overlying volcanic rocks have $\delta^{34} \mathrm{~S}$ and $\Delta^{33} \mathrm{~S}$ values close to $0 \%$, whereas the Fe isotope composition of these samples is -0.17 and $+0.16 \%$, respectively.

The Mozaan Contact Reef occurs at the base of the Mozaan Group, Pongola Supergroup and rests along an angular unconformity on basalts of the volcano-sedimentary Nsuze Group in the Pongola Basin. Its age is poorly constrained between 2.98 and $2.87 \mathrm{Ga}$ (Hegner et al., 1994) but it was likely deposited at c. $2.95 \mathrm{Ga}$. Rounded, massive pyrites show a relatively small range of $\delta^{34} \mathrm{~S}$ values ( 0.2 to $2.9 \%$; Fig. $3 \mathrm{~b}$ ) and a small, but consistently positive $\Delta^{33} \mathrm{~S}$ composition ( 0.10 to $0.21 \%$ ). The $\mathrm{Fe}$ isotope values range from -0.8 to $-0.4 \%$, with the average $\delta^{56} \mathrm{Fe}$ value of $-0.64 \%$ ( $\mathrm{n}=16$; Table S1, Fig. 4). Difference up to $0.21 \%$ has been noted in the analysis of bulk pyrite samples and pyrite fragments, the latter being consistently more negative. Rounded pyrites with a radial texture that strongly resembles the texture of marcasite are common in the reef but proved difficult to analyse for sulphur isotopes due to sputtering when heated with the $\mathrm{CO}_{2}$ laser. After conversion to $\operatorname{Ag}_{2} \mathrm{~S}$, one grain yielded a strongly negative $\delta^{34} \mathrm{~S}$ value and a $\Delta^{33} \mathrm{~S}$ value within the range of the other grains analysed. $\mathrm{Fe}$ isotope analysis of two similar grains yielded $\delta^{56} \mathrm{Fe}$ values of $-1.1 \%$.

Rounded pyrites, both massive and porous, from the c. 2.85 Ga Kimberley Reef of the Central Rand Group of the Witwatersrand Supergroup, Witwatersrand Basin (Kositcin and Krapez, 2004) show a narrow range of $\delta^{34} \mathrm{~S}$ values (-0.2 to $3.7 \%$; Fig. $\left.3 \mathrm{c}\right)$, with the exception of two outliers at 10.7 and $16.3 \%$. Several grains show a negative NMDF signal with $\Delta^{33} \mathrm{~S}$ values as negative as $-0.46 \%$, although most are close to $0 \%$. All grains that show NMDF also show fractionated $\delta^{56} \mathrm{Fe}$ values between -0.67 and $0.37 \%$, while most other grains have $\delta^{56} \mathrm{Fe}$ values close to $0 \%$.

Pyrites from the Ventersdorp Contact Reef at the base of the Ventersdorp Supergroup, dated at c. $2.72 \mathrm{Ga}$ (Armstrong et al, 1991; Kositcin and Krapez, 2004), have similar S 
isotope composition to Kimberley Reef pyrite. Rounded and cubic pyrites show a narrow range of $\delta^{34} \mathrm{~S}$ values $(-1.5$ to $4.3 \%$; Fig. 3c). Several grains have a negative NMDF signal with $\Delta^{33} \mathrm{~S}$ values as negative as $-0.47 \%$. In contrast, Fe isotope composition displays a larger range than for the Kimberley Reef pyrite, with $\delta^{56} \mathrm{Fe}$ values ranging from -0.74 to $1.21 \%$, while most grains, including cubic pyrites, have positive values (Fig. 4). Notably, the large spread of $\delta^{56} \mathrm{Fe}$ values, toward both positive and negative values, is found in pyrite lacking NMDF.

Rounded pyrites from samples of the c. 2.64 Ga Black Reef of the Transvaal Supergroup in the Transvaal Basin (Walraven and Martini, 1995) collected from adjacent mines show a range of $\delta^{34} \mathrm{~S}$ values between -5.6 and $3.2 \%$ with one outlier at $9.1 \%$ (Fig. 3d). Several grains have a strongly negative NMDF signal with $\Delta^{33} \mathrm{~S}$ values as negative as $-1.35 \%$. Except for the outlier, $\delta^{34} \mathrm{~S}$ and $\Delta^{33} \mathrm{~S}$ values show a positive linear correlation. Both massive and porous grains lie on this trend. Pyrite grains, regardless of their $\mathrm{S}$ isotope signature, show $\delta^{56} \mathrm{Fe}$ values ranging from -0.6 to $1.2 \%$ (Fig. 4). The high $\delta^{56} \mathrm{Fe}$ values for pyrite found in the Black Reef and Ventersdorp Contact Reef (up to $1.2 \%$ ) are the highest $\delta^{56} \mathrm{Fe}$ values observed so far for Archaean Fe-sulphide minerals (Rouxel et al., 2005).

The trace element concentrations of pyrites from the different reefs are highly variable (Table S1). With the exception of three samples, pyrites from the Mozaan Contact Reef are characterised by low concentrations of most trace metals (e.g. Ni $(<120$ ppm), As $(<700$ $\mathrm{ppm})$, $\mathrm{Co}(<110 \mathrm{ppm}))$. Large differences in the concentration of $\mathrm{As}, \mathrm{Cr}, \mathrm{Co}, \mathrm{Ag}, \mathrm{Sb}, \mathrm{Au}, \mathrm{Pb}$, $\mathrm{Bi}$, and $\mathrm{U}$ between bulk samples and pyrite fragments from this reef indicate some sample heterogeneity. Pyrites from the Kimberley and Black Reefs show high Ni ( $>520$ ppm) and As (>350 ppm) values as well as variable but generally high $\mathrm{Al}$ abundances $(0.17 \mathrm{wt} \%$ on average). $U$ concentrations are high in the Kimberley Reef pyrite ( $>125 \mathrm{ppm})$, although this element most likely occurs as fine uraninite inclusions within the pyrite. Trace element concentrations of pyrite from the Ventersdorp Contact Reef are the most variable, resulting in the lack of distinct element correlations. Differences in absolute concentrations and ratios of certain elements (e.g. Co/Ni vs. As, Fig. 5) allow differentiation of pyrites from different reefs. $\mathrm{Co}$ and $\mathrm{Ni}$ substitute for $\mathrm{Fe}$ in pyrite and their absolute concentrations and ratios has been used, with a limited success, in the past as a provenance indicator (Meyer et al., 1990). As and Au are enriched in secondary pyrite (England et al., 2002), and may thus be used as an indicator of epigenetic hydrothermal processes. Notably, no correlation has been observed between the concentrations of trace elements and $\mathrm{S}$ or Fe isotope compositions. 


\section{Discussion}

Our multiple $\mathrm{S}$ isotope data for rounded pyrites from different Archaean conglomerates clearly indicate their detrital origin. Large $\delta^{34} \mathrm{~S}$ and $\Delta^{33} \mathrm{~S}$ isotope heterogeneities in rounded pyrites of single samples as well as the presence of a NMDF signal in many grains cannot be explained by post-depositional pyritisation of detrital Fe-oxide minerals by epigenetic hydrothermal or metamorphic fluids (e.g. Barnicoat et al., 1997). Our data add to the long list of arguments in favour of a detrital origin for rounded pyrite, such as the presence of abrasion features, sedimentological control on pyrite distribution, geochemical heterogeneity, and U$\mathrm{Pb}$ and Re-Os ages greater than the depositional age (Ramdohr, 1958; Saager, 1970; Hallbauer, 1986; Barton and Hallbauer, 1996; Kirk et al., 2001; England et al., 2002; Minter, 2006).

Detrital pyrite may have been derived from different sources, including (1) sulphides of magmatic, magmatic-hydrothermal or metamorphism-related hydrothermal origin, hosted in granitoid-greenstone terrains of the hinterland of the sedimentary basins, (2) older sedimentary rock successions, and (3) syndepositional to diagenetic intraformational sulphides representing primary chemical precipitates, early diagenetic products, or secondary replacements. While laminated, radially-textured, and porous pyrite varieties are likely derived from sedimentary sources, such as shales with diagenetic sulphides, sedimentary exhalative deposits, and volcanogenic massive sulphides, the source of massive pyrite grains is equivocal (England et al., 2002). Previous sulphur isotope work on single grains from South African gold reefs, using conventional and in situ analytical techniques (England et al., 2002 and references therein), has shown $\delta^{34} \mathrm{~S}$ values typically in the range of -5 to $+5 \%$ for both massive and porous pyrite varieties, with outliers having more positive values up to 30 \%o. Sulphide minerals in Archaean sedimentary rocks typically show a small range of $\delta^{34} \mathrm{~S}$ values close to that of igneous rocks $(0 \pm 5 \%)$ due to low sulphate concentrations in the Archaean oceans (Canfield et al., 2000), while a larger range of $\delta^{34} \mathrm{~S}$ values in sedimentary sulphides is generally attributed to bacterial sulphate reduction in localized sulphate-rich environments (e.g. Shen et al., 2001; Grassineau et al., 2006). However, photochemical S fractionation may also produce a large range in $\delta^{34} \mathrm{~S}$ values (Farquhar et al., 2001) that can be preserved/transferred to sedimentary pyrite; consequently, $\delta^{34} \mathrm{~S}$ values of Archaean sedimentary sulphide and sulphate minerals alone cannot be used as a direct proxy for bacterial sulphate reduction and local high seawater sulphate content. Additional constraints for an igneous vs. sedimentary origin of sulphides as well as photochemical vs. bacterial S isotope fractionation can be derived from the presence of a NMDF signal, which is a 
characteristic feature of sedimentary rocks older than $2.4 \mathrm{Ga}$. By using such arguments one has to keep in mind that time intervals may have existed in the Archaean when the atmospheric oxygen levels exceeded a threshold concentration for preservation of NMDF signal at $\mathrm{pO}_{2}>10^{-5} \mathrm{PAL}$ (Ohmoto et al., 2006; Ono et al., 2006a) or the atmosphere had a different $\mathrm{CO}_{2} / \mathrm{CH}_{4}$ ratio and organic haze thickness resulting in a different pattern of photochemical fractionation of S isotopes (Farquhar et al., 2007; Domagal-Goldman et al., 2008).

A large range of $\delta^{56} \mathrm{Fe}$ values has been observed in Archaean and Paleoproterozoic sedimentary rocks as summarised earlier. Regardless of the exact abiotic and biotic mechanisms leading to $\mathrm{Fe}$ isotope fractionation in the Archaean sedimentary rock record, which is still a matter of controversy, the presence of highly negative and variable Fe isotope compositions in rounded pyrites provide a clear evidence for a sedimentary, and, potentially, black shale source and can thus be used for provenance evaluation.

\subsection{Origin of the Cheshire Formation pyrites}

Grassineau et al. $(2000,2006)$ reported a range of $\delta^{34} \mathrm{~S}$ values from $-21 \%$ to $+17 \%$ for sulphides at the top of the Manjeri Formation of the Belingwe Greenstone Belt in Zimbabwe, the widest range yet observed in Archaean sedimentary rocks. Rounded pyrites from the Cheshire Formation show a similarly large spread in $\delta^{34} \mathrm{~S}$ values, with negative $\Delta^{33} \mathrm{~S}$ values like those of the Manjeri Formation sulphides (Fig. 3a). These values differ from those of sedimentary sulphides in the Cheshire shales, showing essentially positive $\Delta^{33} \mathrm{~S}$ values, suggesting that rounded pyrites cannot be derived by intraformational reworking of shalehosted sedimentary sulphides. Instead, the large spread of negative $\Delta^{33} \mathrm{~S}$ values indicates a detrital origin, with pyrite derived from erosion of massive sulphides of the Manjeri Formation that were present in the likely source area of the Cheshire Formation (cf. Hofmann et al., 2003). The same conclusion is further supported by the remarkable similarity in $\mathrm{Fe}$ isotope composition of rounded Cheshire pyrites and Manjeri sulphides (Fig. 4), indicating the usefulness of coupled multiple $\mathrm{S}$ and Fe isotope analysis for provenance reconstructions. Archer and Vance (2006) observed a positive co-variation between $\delta^{56} \mathrm{Fe}$ and $\delta^{34} \mathrm{~S}$ values for sulphides of the Manjeri Formation and we also observe a similar trend (Fig. 4a). We note, however, that the opposite trend is evident in our dataset for the rounded Cheshire pyrites.

The origin of massive sulphides at the top of the Manjeri Formation has not been fully investigated and is beyond the scope of this paper. $\mathrm{Fe}$ and $\mathrm{S}$ isotope data may argue for a sedimentary-exhalative (sedex) origin, with $\mathrm{Fe}$ and $\mathrm{S}$ likely remobilized from underlying 
sulphidic black shale due to hydrothermal circulation. The data thus suggest a potential for sedex base metal mineralisation in the Manjeri Formation. The good agreement in the isotope data of the detrital grains and the likely source rocks indicates that the Manjeri massive sulphides must have been relatively homogeneous isotopically over a large area, thus reflecting a uniform process for their origin. However, base metal concentrations must have varied laterally, as indicated by higher base metal contents in rounded pyrites of the Cheshire Formation. Furthermore, rounded pyrites of the Cheshire Formation have higher $\mathrm{Co} / \mathrm{Ni}$ ratios and less negative $\Delta^{33} \mathrm{~S}$ values with respect to the Manjeri massive sulphides (Figs. 4 and 5). We infer that massive sulphides in the source area for the Cheshire rounded pyrites were precipitated from higher temperature and/or proximal submarine hydrothermal fluids compared with the Manjeri massive sulphides. Accepting herein proposed origin for massive sulphides of the Manjeri Formation and rounded pyrites of the Cheshire Formation, the

positive and negative co-variations between $\delta^{56} \mathrm{Fe}$ and $\delta^{34} \mathrm{~S}$ values displayed by these two sets of sulphides (Fig. 4a) might reflect mixing and non-biological fractionation in low and high temperature hydrothermal fluids rather than biologically coupled Fe(III) and sulphate reduction (cf. Archer and Vance, 2006).

\subsection{Crustal origin of Dominion Reef pyrite}

The relatively unfractionated $\delta^{34} \mathrm{~S}$ values and the $\Delta^{33} \mathrm{~S}$ compositions (Fig. 3b) within the MDF range $(0.0 \pm 0.2 \%$, Farquhar and Wing, 2003) in rounded pyrite of the Dominion Reef may indicate a magmatic or high-temperature metamorphism-related hydrothermal provenance, such as the sulphide-quartz veins found in the basement of the Dominion Group. This is supported by the absence of porous pyrites in our sample from this reef. Dominion Reef pyrite and chalcopyrite from underlying and overlying rocks display a relatively small range of $\delta^{56} \mathrm{Fe}$ values, which is within the range of igneous $\delta^{56} \mathrm{Fe}$ values in mantle-derived rocks, including bulk rocks and mineral separates (Poitrasson and Freydier, 2005; Heimann et al., 2008; Teng et al., 2008; Schoenberg et al., 2009). This range is also consistent with experimental studies of $\mathrm{Fe}$ isotope fractionation at magmatic temperatures (Shuessler et al., 2007; Shahar et al., 2008).

\subsection{Sedimentary origin of the Mozaan Contact Reef pyrite}

All pyrites from the Mozaan Contact Reef have small but consistently positive $\Delta^{33} \mathrm{~S}$ values that could reflect NMDF (Fig. 3b). Negative $\delta^{56} \mathrm{Fe}$ values are supportive of either a sedimentary or volcanogenic massive sulphide origin. The radial pyrite from the Mozaan 
Contact Reef has highly negative $\delta^{34} \mathrm{~S}$ values and small positive $\Delta^{33} \mathrm{~S}$ signal, suggesting microbial disproportionation of photochemically-produced elemental sulphur (arrow in Fig. 3b; cf. Philippot et al., 2007). Its derivation from a sedimentary source is also consistent with its marcasite-like texture and highly negative Fe isotope values. Marcasite converts to pyrite at elevated temperatures (Lennie and Vaughan, 1992) and therefore would not have survived greenschist facies metamorphism experienced by the Pongola Supergroup. Since all pyrites, including the radial ones, have very similar $\Delta^{33} \mathrm{~S}$ values, we conclude that they were all derived by erosion of a compositionally homogeneous sedimentary source.

The small range of $\Delta^{33} \mathrm{~S}$ values is consistent with that found in some sedimentary and early diagenetic pyrites formed between 2.7 and 3.2 Ga (Farquhar et al., 2000; Ohmoto et al., 2006; Farquhar et al., 2007; Domagal-Goldman et al., 2008). Small, and predominantly positive, $\Delta^{33} \mathrm{~S}$ values have also been reported by Ono et al. (2006b) for Mozaan Group shales higher up in the stratigraphy.

\subsection{Multiple origins of detrital pyrite from $<2.9$ Ga conglomerate reefs}

Pyrite grains in sedimentary successions younger than 2.9 Ga have more variable multiple $\mathrm{S}$ and $\mathrm{Fe}$ isotope compositions, with remarkable positive $\delta^{56} \mathrm{Fe}$ values up to $1.2 \%$ (Fig. 4). There is no discernible difference in multiple $\mathrm{S}$ and $\mathrm{Fe}$ isotope values between massive and porous varieties and both grain types carry a NMDF signal. This is not surprising, as both types have been observed to co-occur and form distinct domains in the same rounded grains (Fig. 2d, e, and f). We consider that a strong NMDF signal together with variable Fe isotope values ranging between -0.7 and $0.4 \%$ in several rounded grains from the Kimberley Reef suggests their derivation from sedimentary pyrite, while the other grains lacking NMDF signal and having near crustal $\delta^{56} \mathrm{Fe}$ values $(0.1 \pm 0.2 \%$ ) are likely derived from igneous or high-temperature hydrothermal sources. Two grains in the Kimberley Reef have highly positive $\delta^{34} \mathrm{~S}$ values that might indicate sulphate reduction in a closed sulphate-limited system (cf. Ohmoto and Felder, 1987). One of these two grains has moderately negative $\Delta^{33} \mathrm{~S}$ value, which is consistent with $\mathrm{S}$ contribution from photochemically-produced sulphate aerosols (Farquhar et al., 2001). Many grains from the Ventersdorp Contact Reef have both $\delta^{34} \mathrm{~S}$ and $\Delta^{33} \mathrm{~S}$ values close to $0 \%$, but do show highly variable positive and negative Fe isotope values, suggesting that they were also derived from a sedimentary source containing sulphur without significant NMDF signal.

Euhedral pyrites are secondary features related to diagenesis, metamorphism or hydrothermal alteration. England et al. (2002) reported $\delta^{34} \mathrm{~S}$ values of -0.5 to $2.5 \%$ for 
euhedral pyrites of the Steyn Reef (Central Rand Group of the Witwatersrand Basin), a narrower range than that of rounded pyrite grains, which supports a hydrothermalmetamorphic origin for these grains. The few euhedral grains analysed in this study from the Ventersdorp Contact Reef have $\delta^{34} \mathrm{~S}$ values close to $0 \%$, but one of them shows a moderately negative NMDF signal and two grains exhibit strongly positive $\delta^{56} \mathrm{Fe}$ values. These data most likely reflect the presence of a core of rounded pyrite within the cubic grains, a feature that is common for the Ventersdorp Contact Reef (England et al., 2002; Frimmel, 2005).

Rounded pyrite grains from single hand specimens herein discussed show a large range in $\delta^{34} \mathrm{~S}, \Delta^{33} \mathrm{~S}$ and $\delta^{56} \mathrm{Fe}$ values. Similar heterogeneity for $\delta^{34} \mathrm{~S}$ values (England et al., 2002) and trace element composition of pyrite grains (Barton and Hallbauer, 1996) has been reported previously. Two different samples of the Black Reef also show a large variation in $\mathrm{S}$ isotope values. There is a well-developed positive correlation between $\delta^{34} \mathrm{~S}$ and $\Delta^{33} \mathrm{~S}$ values in the pyrite grains from the Black Reef samples. This trend probably indicates that all grains were derived by erosion of a sedimentary source that obtained its isotope composition over a short time interval from a distinct photochemical process, an explanation which would be in agreement with models that argue for an intraformational origin of pyrite (e.g. Hallbauer, 1986). Different trends have been observed for different Archaean time intervals and may reflect changes in atmospheric composition or the formation of organic haze in the atmosphere (cf. Farquhar et al., 2007; Domagal-Goldman et al., 2008). Alternatively, the covariation in $\delta^{34} \mathrm{~S}$ and $\Delta^{33} \mathrm{~S}$ values could reflect a combination of mass-dependent and nonmass dependent isotope effects, as suggested by Ono et al. (2003), Ueno et al. (2008), and Shen et al. (2009).

All rounded pyrites that show a significant NMDF signal have negative $\Delta^{33} \mathrm{~S}$ values. This might indicate their derivation from pyrites that formed as a result of reduction of seawater sulphate at least partially derived from photochemically-fractionated sulphate aerosols. A similar NMDF signal is common to sulphides from chemical precipitates, such as deep-water VMS deposits and BIFs (Farquhar and Wing, 2005; Jamieson et al., 2006; Ueno et al., 2008; Bekker et al., 2008b). In c. $2.7 \mathrm{Ga}$ organic matter-rich shales from different greenstone belts in Zimbabwe (Bekker et al., 2008a) and in c. 2.5 Ga Klein Naute Formation of the Transvaal Supergroup, South Africa (Ono et al., 2009) early diagenetic pyrite nodules carry mostly negative $\Delta^{33} \mathrm{~S}$ values and occur in a matrix of shale with disseminated pyrite having highly positive $\Delta^{33} \mathrm{~S}$ values. We infer therefore that rounded pyrites with negative $\Delta^{33} \mathrm{~S}$ signal were derived either from sedimentary pyrite nodules or VMS deposits and were concentrated in the 
heavy fraction of conglomerates, whereas fine-grained pyrites were dispersed into low-energy depositional environments.

\subsection{Origin of rounded pyrite with highly positive $\delta^{56} \mathrm{Fe}$ values}

Rounded pyrite grains with highly positive $\delta^{56} \mathrm{Fe}$ values up to $1.2 \%$ are present in the Ventersdorp Contact Reef and the Black Reef (Fig. 4). The origin and significance of these unusual values are unclear. Using reduced isotopic partition function ratios for $\mathrm{FeS}_{2}$ and Fe(II)-aquachloro complexes determined previously (Polyakov, 1997; Polyakov and Mineev, 2000; Schauble et al., 2001; Polyakov et al., 2007), the isotope fractionation factors $\alpha$ between $\mathrm{FeS}_{2}$ and $\mathrm{FeCl}_{4}{ }^{2-}$ or $\mathrm{Fe}\left(\mathrm{H}_{2} \mathrm{O}\right)_{6}{ }^{2+}$ are $\sim 1.0015$ at $350^{\circ} \mathrm{C}$. Although these positive fractionation factors are opposite to the kinetic isotope fractionation during FeS precipitation, either from $\mathrm{Fe}(\mathrm{II})_{\mathrm{aq}}$ solutions at room temperature (Butler et al., 2005) or from silicate melt at magmatic temperatures (Schuessler et al., 2007), it may explain the occurrence of positive $\delta^{56} \mathrm{Fe}$ values in recrystallised pyrite. Under this scenario, $\delta^{56} \mathrm{Fe}$ of primary pyrite is modified by metamorphic overprint and $\mathrm{Fe}$ isotope re-equilibration with metamorphic fluids. The problem with this scenario is the lack of evidence for recrystallisation, especially for the Black Reef, and the absence of rounded pyrite grains with highly positive $\delta^{56} \mathrm{Fe}$ values in any of the other reefs investigated.

A different interpretation involves sulphidisation of Fe-oxide minerals for the origin of these grains, as positive $\delta^{56} \mathrm{Fe}$ values have so far been described mainly from BIFs in the Archaean rock record (Johnson et al., 2003; Dauphas et al., 2004; Rouxel et al., 2005; Whitehouse and Fedo, 2007). Evidence for sulphidisation of Fe and Fe-Ti oxides, such as magnetite and ilmenite, collectively referred as "black sands", as well as BIF clasts has been observed in previous studies (Ramdohr, 1958) and resulted in a long-standing debate on the timing of sulphidisation, with the "placerists" arguing for pre-depositional sulphidisation (Ramdohr, 1958; Reimer and Mossman, 1990) and the "hydrothermalists" arguing for postdepositional sulphidisation of "black sands" (Barnicoat et al., 1997; Law and Phillips, 2006). While Fe isotope analysis may help to detect sulphidised Fe oxides, it may not help to resolve where, when, and by what process sulphidisation happened. However, multiple sulphur isotope values are highly variable for grains with positive $\delta^{56} \mathrm{Fe}$ values, indicating that if sulphidisation took place, it happened prior to deposition, as they were not homogenised by post-depositional fluids as inferred in the hydrothermal model of pyritisation and gold mineralisation. The above interpretation hinges on the presence of pre-2.7 Ga BIFs with 
positive Fe isotope values in the source area of the Witwatersrand Basin. However, magnetite in shales from the West Rand Group have negative $\delta^{56} \mathrm{Fe}$ values (Yamaguchi et al., 2005).

\subsection{Trace element composition of rounded pyrites in reef conglomerates}

Variations in the trace element composition of pyrites from single hand specimen have been reported in previous studies (Meyer et al., 1990; Barton and Hallbauer, 1996) and have been attributed, at least partially, to different sources of the detrital grains. Massive pyrites generally have lower concentrations of trace elements than porous pyrites (Barton and Hallbauer, 1996). This corresponds with the low trace element contents in the predominantly massive grains from the Mozaan Contact Reef and the elevated concentrations in the Kimberley and Black Reef pyrites, which are commonly porous and contain Al-silicate inclusions, as indicated by their high $\mathrm{Al}$ abundances (Table $\mathrm{S} 1$ ). While variations in the composition of pyrites from different reefs probably correspond with different provenance areas, compositional variation of pyrite from reefs that contain pyrite with a narrow range of $\mathrm{S}$ and $\mathrm{Fe}$ isotope values, such as the Mozaan Contact Reef, likely reflects the presence of inclusions, such as arsenopyrite, galena, and gold that are commonly encountered in rounded pyrites (Ramdohr, 1958). The observation that many inclusions are secondary in origin (Ramdohr, 1958), evidence for remobilization of elements susceptible to hydrothermal alteration, such as Au, Ni, and As (Meyer et al., 1990; England et al., 2002), and the lack of correlation between isotope and trace element compositions (this study) does suggest, however, that the hydrothermal overprint experienced by the reefs masked the provenance signal potentially recorded in the trace element compositions, indicating a higher potential of combined multiple $\mathrm{S}$ and $\mathrm{Fe}$ isotope studies over trace element analysis for provenance studies of detrital sulphides.

\section{Conclusions}

Multiple $\mathrm{S}$ and $\mathrm{Fe}$ isotope composition of massive and porous pyrites forming rounded grains in coarse clastic Archaean strata is consistent with their detrital origin. We have established a crustal source, possibly quartz veins in granitoid-greenstone terrains, for pyrites from a c. $3.1 \mathrm{Ga}$ conglomerate horizon. Pyrites derived from a sedimentary source occur in a c. $2.95 \mathrm{Ga}$ reef horizon, as indicated by a small NMDF signal and negative $\delta^{56} \mathrm{Fe}$ values, and show $\delta^{34} \mathrm{~S}$ values consistent with microbial disproportionation of photochemically-produced elemental sulphur during deposition of sedimentary units in the source area. Younger reef conglomerates contain abundant sediment-derived pyrite grains, which is consistent with the 
increase in sedimentary cover on the Kaapvaal Craton with time. Sediment-derived pyrite becomes strongly fractionated in terms of $\Delta^{33} \mathrm{~S}$ composition in conglomerates younger than $2.7 \mathrm{Ga}$, whereas $\Delta^{33} \mathrm{~S}$ values range from -0.5 to $0.25 \%$ for conglomerates deposited between 3.1 and $2.7 \mathrm{Ga}$, consistent with a secular variation in $\Delta^{33} \mathrm{~S}$ values through time (cf. Farquhar et al., 2007). Coupled $\mathrm{S}$ and Fe isotope analysis has shown the potential presence of pyrites in the conglomerate reefs that formed by sulphidisation of Fe oxides in the provenance area. It has also indicated that the source area of a c. 2.7 Ga conglomerate bed contained Archaean sedimentary sulphides without NMDF signal. However, the abundance of detrital pyrite grains in the c. 3.1-2.7 Ga reefs suggests that a small range of NMDF of sulphur recorded in this time interval is not likely to reflect high atmospheric oxygen levels. Using strata of the Belingwe greenstone belt as a case study, we were able to identify the likely source for rounded pyrite grains in a shale-hosted massive sulphide deposit, indicating the usefulness of multiple $\mathrm{S}$ and $\mathrm{Fe}$ isotope study in the provenance analysis of Archaean sedimentary successions.

\section{Acknowledgements}

AH acknowledges support by NAI International Collaboration Grant and NRF grant FA2005040400027. AB participation was supported by NSF grant EAR-937 05-45484, NAI award No. NNA04CC09A, and NSERC 938 Discovery grant. Rouxel's contribution was supported by NSF OCE-0622982. We thank Pieter van Zyl (AngloGold Ashanti) and Tanja Reinhardt (UKZN) for providing sample material and Boswell Wing and Emilie Thomassot (McGill University) for converting 'jumpy' pyrite grain to $\mathrm{Ag}_{2} \mathrm{~S}$. Careful reviews by two anonymous reviewers as well as editorial handling by T.M. Harrison are gratefully acknowledged.

\section{References}

Anbar, A.D., Rouxel, O., 2007. Metal stable isotopes in paleoceanography. Annu. Rev. Earth Planet. Sci. 35, 717-746.

Archer, C., Vance, D., 2006. Coupled Fe and S isotope evidence for Archean microbial $\mathrm{Fe}(\mathrm{III})$ and sulfate reduction. Geology 34, 153-156.

Armstrong, R.A., Compston, W., Retief, E.A., William, L.S., Welke, H.J., 1991. Zircon ion microprobe studies bearing on the age and evolution of the Witwatersrand triad. Precambrian Res. 53, 243-266. 
Barnicoat, A.C., Henderson, I.H.C., Knipe, R.J., Yardley, B.W. D., Napier, R.W., Fox, N.P.C., Kenyon, A.K., Muntingh, D.J., Strydom, D., Winkler, K.S., Lawrence, S.R., Cornford, C., 1997. Hydrothermal gold mineralization in the Witwatersrand basin. Nature $386,820-824$.

Barton, E.S., Hallbauer, D.K., 1996. Trace-element and U-Pb isotope compositions of pyrite types in the Proterozoic Black reef, Transvaal sequence, South Africa: implications on genesis and age. Chem. Geol. 133, 173-199.

Beard, B.L., Johnson, C.M., von Damm, K.L., Poulson, R.L., 2003. Iron isotope constraints on Fe cycling and mass balance in oxygenated Earth oceans. Geology 31, 629-631.

Bekker, A., Hofmann, A., Rumble, D., Rouxel, O., 2008a. Sulfidic organic-rich shales in the Archean low-sulfate ocean: Evidence for transient oxygenated conditions, enhanced volcanism, or low sedimentation rates? Geochim. Cosmochim. Acta 72, Supplement 1, A69.

Bekker, A., Barley, M.E., Fiorentini, M.L., Rouxel, O.J., Rumble, D., Beresford, S.W., 2008b. Multiple S and Fe isotope constraints on the origin of NiS mineralization hosted in Archean komatiites. Geophysical Research Abstracts, EGU2008-A-11593.

Butler, I.B., Archer, C., Vance, D., Oldroyd, A., Rickard, D., 2005. Fe isotope fractionation on FeS formation in ambient aqueous solution. Earth Planet. Sci. Lett. 236, 430-442.

Canfield, D.E., Habicht, K.S., Thamdrup, B., 2000. The Archean sulfur cycle and the early history of atmospheric oxygen. Science 288, 658-661.

Dauphas, N., Rouxel O.J., 2006. Mass spectrometry and natural variations of iron isotopes. Mass Spectrom. Rev. 25, 515-550.

Dauphas, N., van Zuilen, M., Wadhwa, M., Davis, A.M., Marty, B., Janney, P.E., 2004. Clues from $\mathrm{Fe}$ isotope variations on the origin of early Archean BIFs from Greenland. Science 306, 2077-2080.

Domagal-Goldman, S.D., Kasting, J.F., Johnston, D.T., Farquhar, J., 2008. Using multiple sulfur isotopes to constrain Archean atmosphere. Earth Planet. Sci. Lett. 269, 29-40.

England, G.L., Rasmussen, B., Krapez, B., Groves, D.I., 2002. Palaeoenvironmental significance of rounded pyrite in siliciclastic sequences of the Late Archaean Witwatersrand Basin: oxygen-deficient atmosphere or hydrothermal evolution. Sedimentology 49, 1122-1156.

Farquhar, J., Wing, B.A., 2003. Multiple sulfur isotopes and the evolution of the atmosphere. Earth Planet. Sci. Lett. 213, 1-13. 
Farquhar, J., Wing, B.A., 2005. The terrestrial record of stable sulphur isotopes: a review of the implications for evolution of Earth's sulphur cycle. In: McDonald, I., Boyce, A.J., Butler, I.B., Herrington, R.J., Polya, D.A. (Eds.), Mineral Deposits and Earth Evolution. Geol. Soc. Lond. Spec. Publ. 248, pp. 167-177.

Farquhar, J., Bao, H., Thiemens, M., 2000. Atmospheric influence of Earth's earliest sulfur cycle. Science 289, 756-758.

Farquhar J., Savarino J., Airieau S., Thiemens M.H., 2001. Observation of wavelengthsensitive mass-independent sulfur isotope effects during $\mathrm{SO}_{2}$ photolysis: Implications for the early atmosphere. J. Geophys. Res.106, 1-11.

Farquhar, J., Peters, M., Johnston, D.T., Strauss, H., Masterson, A., Wiechert, U., Kaufman, A.J., 2007. Isotopic evidence for Mesoarchean anoxia and changing atmospheric sulfur chemistry. Nature 499, 706-711.

Feather, C.E., Koen, G.M., 1975. The Mineralogy of the Witwatersrand reefs. Min. Sci. Eng. 7, 189-223.

Frimmel, H.E., 2005. Archaean atmospheric evolution: evidence from the Witwatersrand gold fields, South Africa. Earth-Science Rev. 70, 1-46.

Frimmel, H.E., 2008. Earth's continental crustal gold endowment. Earth Planet. Sci. Lett. 267, $45-55$.

Grassineau, N.V., Abell, P., Appel, P.W.U., Lowry, D., Nisbet, E.G. 2006. Early life signatures in sulfur and carbon isotopes from Isua, Barberton, Wabigoon (Steep Rock), and Belingwe Greenstone Belts (3.8 to 2.7 Ga). In: Kesler, S.E., Ohmoto, H., (Eds.), Evolution of Early Earth's Atmosphere, Hydrosphere and Biosphere - Constraints from Ore Deposits. Geol. Soc. Am. Mem. 198, pp. 33-52.

Grassineau, N.V., Nisbet, E.G., Bickle, M.J., Fowler, C.M.R., Lowry, D., Mattey, D.P., Abell, P., Martin, A., 2000. Antiquity of the biological sulphur cycle: evidence from sulphur and carbon isotopes in 2700 million-year-old rocks of the Belingwe Belt, Zimbabwe. Proc. R. Soc. Lond. B 268, 113-119.

Hallbauer, D.K., 1986. The mineralogy and geochemistry of Witwatersrand pyrite, gold, uranium, and carbonaceous matter. In: Anhaeusser, C.R., Maske, S. (Eds.), Mineral Deposits of Southern Africa. Geol. Soc. S. Afr., Johannesburg, pp. 731- 752.

Hegner, E., Kröner, A., Hunt, P., 1994. A precise U-Pb zircon age for the Archaean Pongola Supergroup volcanics in Swaziland. J. Afr. Earth Sci. 18, 339-341. 
Heimann, A., Beard, B.L., Johnson, C.M., 2008. The role of volatile exsolution and subsolidus fluid/rock interactions in producing high ${ }^{56} \mathrm{Fe} /{ }^{54} \mathrm{Fe}$ ratios in siliceous igneous rocks: Geochim. Cosmochim. Acta 72, 4379-4396.

Hiemstra, S.A., 1968. The mineralogy and petrology of the uraniferous conglomerate of the Dominion Reefs Mine, Klerksdorp area. Trans. Geol. Soc. S. Afr. 71, 1-65.

Hofmann, A., Kusky, T.M., 2004. The Belingwe greenstone belt: ensialic or oceanic? In: Kusky, T.M. (Ed.), Precambrian Ophiolites and Related Rocks. Developments in Precambrian Geology 13, Elsevier, Amsterdam, pp. 487-537.

Hofmann, A., Dirks, P.H.G.M., Jelsma, H.A., 2001. Late Archaean foreland basin deposits, Belingwe greenstone belt, Zimbabwe. Sed. Geol. 141-142, 131-168.

Hofmann, A., Bolhar, R., Dirks, P.H.G.M., Jelsma, H.A., 2003. The geochemistry of Archaean shales derived from a mafic volcanic sequence, Belingwe greenstone belt, Zimbabwe: provenance, source area unroofing and submarine vs subaerial weathering. Geochim. Cosmochim. Acta, 67, 421-440.

Holland, H.D., 1984. Chemical Evolution of the Atmosphere and Oceans. Princeton University Press, Princeton, 582 pp.

Hu, G.X., Rumble, D., Wang, P.L., 2003. An ultraviolet laser microprobe for the in situ analysis of multisulfur isotopes and its use in measuring Archean sulfur isotope massindependent anomalies. Geochim. Cosmochim. Acta 67, 3101-3118.

Hulston, J.R., Thode, H.G., 1965. Variations in the S33, S34, and S36 contents of meteorites and their relation to chemical and nuclear effects. J. Geophys. Res. 70, 3475-3484.

Hunter, M.A., Bickle, M.J., Nisbet, E.G., Martin, A., Chapman, H.J., 1998. Continental extensional setting for the Archean Belingwe Greenstone Belt, Zimbabwe. Geology 26, 883-886.

Jamieson, J.W., Wing, B.A., Hannington, M.D., Farquhar, J., 2006. Evaluating isotopic equilibrium among sulfide mineral pairs in Archean ore deposits: case study from the Kidd Creek VMS deposit, Ontario, Canada. Econ. Geol. 101, 1055-1061.

Johnson, C.M., Beard, B.L., Beukes, N.J., Klein, C., O’Leary, J.M., 2003. Ancient geochemical cycling in the Earth as inferred from $\mathrm{Fe}$ isotope studies of banded iron formations from the Transvaal Craton. Contrib. Miner. Petrol. 144, 523-547.

Johnson, C.M., Beard, B.L., Roden, E.E., 2008. The Iron Isotope Fingerprints of Redox and Biogeochemical Cycling in Modern and Ancient Earth. Annu. Rev. Earth Planet. Sci. 36, $457-493$. 
Kirk, J., Ruiz, J., Chesley, J., Titley, S., Walshe, J., 2001. A detrital model for the origin of gold and sulfides in the Witwatersrand basin based on Re-Os isotopes. Geochim. Cosmochim. Acta 65, 2149-2159.

Krupp, R., Oberthür, T., Hirdes, W., 1994. The Early Precambrian atmosphere and hydrosphere: thermodynamic constraints from mineral deposits. Econ. Geol. 89, 15811598.

Kositcin, N., Krapez, B., 2004. SHRIMP U-Pb detrital zircon geochronology of the Late Archaean Witwatersrand Basin of South Africa: relation between zircon provenance age spectra and basin evolution. Precambrian Res. 129, 141-168.

Law, J., Phillips, N., 2006. Witwatersrand gold-pyrite-uraninite deposits do not support a reducing Archean atmosphere. In: Kessler, S.E., Ohmoto, H., (Eds.), Evolution of Early Earth's Atmosphere, Hydrosphere and Biosphere-Constraints from Ore Deposits. Geol. Soc. Am. Mem. 198, pp. 121-141.

Lennie, A.R. Vaughan, D.J., 1992. Kinetics of the marcasite-pyrite transformation: An infrared spectroscopic study. Am. Mineralogist 77, 1166-1171.

Meyer, F.M., Oberthür, T., Robb, L.J., Saager, R. Stupp, H.D., 1990. Cobalt, nickel and gold in pyrite from primary gold deposits and Witwatersrand reefs. S. Afr. J. Geol. 93, 70-82.

Miller, M.F., 2002. Isotopic fractionation and the quantification of ${ }^{17} \mathrm{O}$ anomalies in the oxygen three-isotope system: an appraisal and geochemical significance. Geochim. Cosmochim. Acta 66, 1881-1889.

Minter, W.E.L., 2006. The sedimentary setting of Witwatersrand placer mineral deposits in an Archean atmosphere. Special volume on the evolution of the earth's atmosphere: In: Kessler, S.E., Ohmoto, H., (Eds.), Evolution of Early Earth's Atmosphere, Hydrosphere and Biosphere - Constraints from Ore Deposits. Geol. Soc. Am. Mem. 198, pp. 105-119.

Ohmoto, H., Felder, R.P., 1987. Bacterial activity in the warmer, sulphate-bearing, Archaean ocean. Nature 328, 244-246.

Ohmoto, H., Watanabe, Y., Ikemi, H., Poulson, S.R., Taylor, B.E., 2006. Sulphur isotope evidence for an oxic Archaean atmosphere. Nature 442, 908-911.

Ono, S., Eigenbrode, J.L., Pavlov, A.A., Kharecha, P., Rumble III, D., Kasting, J.F., Freeman, K.H., 2003. New insights into Archean sulfur cycle from mass-independent sulfur isotope records from the Hamersley Basin, Australia. Earth Planet. Sci. Lett. 213, 15-30.

Ono, S., Wing, B., Johnston, D., Farquhar, J., Rumble, D., 2006a. Mass-dependent fractionation of quadruple stable isotope system as a new tracer of sulfur biogeochemical cycles. Geochim. Cosmochim. Acta 70, 2238-2252. 
Ono, S., Beukes, N.J., Rumble, D., Fogel, M.L., 2006b. Early evolution of atmospheric oxygen from multiple-sulfur and carbon isotope records of the $2.9 \mathrm{Ga}$ Mozaan Group of the Pongola Supergroup, Southern Africa. S. Afr. J. Geol. 109, 97-108.

Ono, S., Beukes, N.J., Rumble, D., 2009. Origin of two distinct multiple-sulfur isotope compositions of pyrite in the $2.5 \mathrm{Ga}$ Klein Naute Formation, Griqualand West Basin, South Africa. Precambrian Res., doi:10.1016/j.precamres.2008.10.012.

Pavlov, A.A., Kasting, J.F., 2002. Mass-independent fractionation of sulfur isotopes in Archean sediments: strong evidence for an anoxic Archean atmosphere. Astrobiology 2, $27-41$.

Philippot, P., van Zuilen, M., Lepot, K., Thomazo, C., Farquhar, J., van Kranendonk, M.J., 2007. Early Archaean microoganisms preferred elemental sulfur, not sulfate. Science 317, $1534-1537$.

Phillips, G.N., Law, J.D.M., 2000. Witwatersrand Gold Fields: Geology, Genesis, and Exploration. SEG Rev. 13, 439-500.

Poitrasson, F., Freydier, R., 2005. Heavy iron isotope composition of granites determined by high resolution MC-ICP-MS. Chem. Geol. 222, 132-147.

Polyakov, V.B., Clayton, R.N., Horita, J., Mineev, S.D., 2007. Equilibrium iron isotope fractionation factors of minerals: Reevaluation from the data of nuclear inelastic resonant X-ray scattering and Mössbauer spectroscopy: Geochim. Cosmochim. Acta 71, 38333846.

Polyakov, V.B., Mineev, S.D., 2000. The use of Mössbauer spectroscopy in stable isotope geochemistry. Geochim. Cosmochim. Acta 64, 849-865.

Polyakov, V.B., 1997. Equilibrium fractionation of the iron isotopes: Estimation from Mössbauer spectroscopy data. Geochim. Cosmochim. Acta 61, 4213-4217.

Ramdohr, P., 1958. New observations on the ores of the Witwatersrand in South Africa and their genetic significance. Trans. Geol. Soc. S. Afr. 61, 1-50.

Rasmussen, B., Buick, R., 1999. Redox state of the Archean atmosphere: evidence from detrital heavy minerals in ca. 3250-2750 Ma sandstones from the Pilbara Craton, Australia. Geology 27, 115-118.

Reimer, T.O., Mossman, D.J., 1990. Sulfidization of Witwatersrand black sands: From enigma to myth. Geology 18, 426-429.

Robb, L.J., Meyer, F.M., 1990. The nature of the Witwatersrand hinterland: conjectures on the source-area problem. Econ. Geol. 85, 511-536. 
Robb, L.J., Davis, D., Kamo, S.L., Meyer, F.M., 1992. Ages of altered granites adjoining the Witwatersrand Basin with implications for the origin of gold and uranium. Nature 357, $677-680$.

Rouxel, O., Fouquet, Y., Ludden, J.N., 2004. Subsurface processes at the Lucky Strike hydrothermal field, Mid-Atlantic Ridge: Evidence from sulfur, selenium, and iron isotopes. Geochim. Cosmochim. Acta 68, 2295-2311.

Rouxel, O., Bekker, A., Edwards, K., 2005. Iron Isotope Constraints on the Archean and Paleoproterozoic Ocean Redox State. Science 307, 1088-1091.

Rouxel, O., Shanks, W.C., Bach, W., Edwards, K., 2008a. Integrated Fe and S isotope study of seafloor hydrothermal vents at East Pacific Rise 9-10N. Chem. Geol. 252, 214-227.

Rouxel, O., Sholkovitz, E., Charette, M., Edwards, K., 2008b. Iron Isotope Fractionation in Subterranean Estuaries. Geochem. Cosmochim. Acta 72, 3413-3430.

Saager, R., 1970. Structures in pyrite from the Basal reef in the Orange Free State Gold-field. Trans. Geol. Soc. S. Afr. 73, 29-46.

Schauble, E.A., Rossman, G.R., Taylor, H.P., 2001. Theoretical estimates of equilibrium Feisotope fractionations from vibrational spectroscopy. Geochim. Cosmochim. Acta 65, 2487-2497.

Schoenberg, R., Marks, M.A.W., Schuessler, J.A., von Blanckenburg, F., Markl, G., 2009. Fe isotope systematics of coexisting amphibole and pyroxene in the alkaline igneous rock suite of the Ilímaussaq Complex, South Greenland. Chem. Geol. 258, 65-77.

Schuessler, J.A., Schoenberg, R., Behrens, H., von Blanckenburg, F., 2007. The experimental calibration of the iron isotope fractionation factor between pyrrhotite and peralkaline rhyolitic melt. Geochim. Cosmochim. Acta 71, 417-433.

Shahar, A., Young, E.D., Manning, C.E., 2008. Equilibrium high-temperature Fe isotope fractionation between fayalite and magnetite: An experimental calibration. Earth Planet. Sci. Lett. 268, 330-338.

Sharma, M., Polizzotto, M., Anbar, A.D., 2001. Iron isotopes in hot springs along the Juan de Fuca Ridge. Earth Planet. Sci. Lett. 194, 39-51.

Shen, Y., Buick, R., Canfield, D.E., 2001. Isotope evidence for microbial sulphate reduction in the early Archean era. Nature 410, 77-81.

Shen, Y., Farquhar, J., Masterson, A., Kaufman, A.J., Buick, R., 2009. Evaluating the role of microbial sulfate reduction in the early Archean using quadruple isotope systematics. Earth Planet. Sci. Lett. 279, 383-391. 
Teng, F.-Z., Dauphas, N., Helz, R.T., 2008. Iron isotope fractionation during magmatic differentiation in Kilauea Iki Lava Lake. Science 320, 1620-1622.

Ueno, Y., Ono, S., Rumble, D., Maruyama, S., 2008. Quadruple sulfur isotope analysis of ca. 3.5 Ga Dresser Formation: New evidence for microbial sulphate reduction in the early Archean. Geochim. Cosmochim. Acta 72, 5675-5691.

Utter, T., 1978. Morphology and geochemistry of different pyrite types from the Upper Witwatersrand System of the Klerksdorp Goldfield, South Africa. Geol. Rundschau 67, 774- 804 .

Walraven, F., Martini, J., 1995. Zircon Pb-evaporation age determinations for the Oak Tree Formation, Chuniespoort Group, Transvaal Sequence; implications for TransvaalGriqualand West basin correlations. S. Afr. J. Geol. 98, 58-67.

Watanabe, Y., Farquhar, J., Ohmoto, H., 2009. Anomalous fractionations of sulfur isotopes during thermochemical sulfate reduction. Science 324, 370-373.

Whitehouse, M.J., Fedo, C.M., 2007. Microscale heterogeneity of Fe isotopes in $>3.71 \mathrm{Ga}$ banded iron formation from the Isua Greenstone Belt, southwest Greenland. Geology 35, $719-722$.

Yamaguchi, K.E., Johnson, C.M., Beard, B.L., Ohmoto, H., 2005. Biogeochemical cycling of iron in the Archean-Paleoproterozoic Earth: constraints from iron isotope variations in sedimentary rocks from the Kaapvaal and Pilbara Cratons. Chem. Geol. 218, 135-169. 


\section{Figure captions}

Fig. 1. Simplified geology of parts of the Kaapvaal and Zimbabwe cratons and sample localities. 1, Belingwe Greenstone Belt; 2, Dominion Reefs Uranium Mine; 3, Denny Dalton Mine; 4, Randfontein Estates Mine; 5, TauTona Mine; 6, East Geduld Mine and Consolidated Modderfontein Mine.

Fig. 2. (a) Mineral separate of rounded pyrite from the Cheshire Formation. Note grain with laminations (arrow). (b) Transmitted/reflected light photomicrograph of rounded pyrite surrounded by detrital quartz of the Mozaan Contact Reef. (c) Reflected light photomicrograph of rounded pyrite from the Black Reef. (d) Reflected light photomicrograph of rounded pyrite from the Ventersdorp Contact Reef. Note concentrically laminated detrital grain and porous grain with veins of massive pyrite (arrows). (e) Reflected light photomicrograph of rounded and cubic pyrite from the Ventersdorp Contact Reef. Note concentrically laminated detrital grain (arrow) and composite grain of massive and porous pyrite. (f) Composite grain of massive and porous pyrite from the Ventersdorp Contact Reef. Pm: massive pyrite, Pp: porous pyrite, Pc: cubic pyrite. Scale bars are $1 \mathrm{~mm}$ in length.

Fig. 3. Plots of $\Delta^{33} \mathrm{~S}$ vs. $\delta^{34} \mathrm{~S}$ values for pyrite (Py) and chalcopyrite (Cpy) from Archaean sedimentary successions of southern Africa. Grey-shaded areas outline the $\Delta^{33} \mathrm{~S}$ range of $0.0 \pm$ $0.2 \%$ reflecting MDF. a) $\mathrm{S}$ isotope data for rounded pyrite from a conglomerate bed in the Cheshire Formation, early diagenetic pyrite from shales of the Cheshire Formation, and massive pyrite from the top of the Manjeri Formation. b) $\mathrm{S}$ isotope data for pyrites from the Dominion Reef (DR) of the Dominion Group and the Mozaan Contact Reef (MCR) of the Pongola Supergroup. Horizontal line with arrows indicates microbial disproportionation of photochemically-produced elemental sulphur. c) $\mathrm{S}$ isotope data for pyrites from the Kimberley Reef (KR) of the Witwatersrand Supergroup and the Ventersdorp Contact Reef (VCR) of the Ventersdorp Supergroup. d) S isotope data for pyrites from the Black Reef of the Transvaal Supergroup. Note that except for one outlier, $\delta^{34} \mathrm{~S}$ and $\Delta^{33} \mathrm{~S}$ values show a strong linear correlation $\left(\Delta^{33} \mathrm{~S} \approx 0.19 * \delta^{34} \mathrm{~S}-0.23, \mathrm{R}^{2}=0.79\right)$.

Fig. 4. Plots of (a) $\delta^{34} \mathrm{~S}$ vs. $\delta^{56} \mathrm{Fe}$ values and (b) $\Delta^{33} \mathrm{~S}$ vs. $\delta^{56} \mathrm{Fe}$ values for pyrites from Archaean sedimentary successions of southern Africa. Fields I to IV are schematic and outline the composition of sulphides from different Archaean environments. See text for references. 
Note that in organic matter-rich shales nodular pyrite has mostly negative $\Delta^{33} \mathrm{~S}$ values, whereas disseminated pyrite has mostly positive $\Delta^{33} \mathrm{~S}$ values.

Fig. 5. Plot of $\mathrm{Co} / \mathrm{Ni}$ vs. As. Pyrites from the Belingwe greenstone belt are characterised by low As and high $\mathrm{Co} / \mathrm{Ni}$ ratios. Good agreement between the values of the massive sulphides of the Manjeri Formation and detrital pyrites of the Cheshire Formation indicates little modification of the pyrite composition during reworking and diagenesis. Samples from the Kimberley and Black Reefs have low $\mathrm{Co} / \mathrm{Ni}$ and high As contents, which may reflect postdepositional hydrothermal alteration. Samples from the Mozaan Contact Reef show large scatter, which is unlikely to result from heterogeneous source area since multiple $\mathrm{S}$ and $\mathrm{Fe}$ isotope compositions are rather homogenous. Ventersdorp Contact Reef pyrite is compositionally the most complex, possibly due to different sources and strong secondary hydrothermal overprint. 
Table 1. Sample description and localities.

\begin{tabular}{|c|c|c|c|c|}
\hline Age $(\mathrm{Ga})$ & Stratigraphy & Unit & Location & Sample description \\
\hline \multicolumn{5}{|c|}{ Belingwe Greenstone Belt, Zimbabwe } \\
\hline c. 2.60 & Cheshire Fm & $\begin{array}{l}\text { Siliciclastic } \\
\text { Member }\end{array}$ & $\begin{array}{l}\text { Section E in } \\
\text { Hofmann et al. } \\
\text { (2001) }\end{array}$ & $\begin{array}{l}\text { Fine-grained basalt pebble } \\
\text { conglomerate with } 10 \text { vol.\% } \\
\text { rounded pyrite granules (sample } \\
\text { B/E1) }\end{array}$ \\
\hline c. 2.60 & Cheshire Fm & $\begin{array}{l}\text { Siliciclastic } \\
\text { Member }\end{array}$ & Agincourt Mine & $\begin{array}{l}\text { Carbonaceous shale with lamina } \\
\text { and veinlets of pyrite (several } \\
\text { samples) }\end{array}$ \\
\hline c. 2.70 & Manjeri Fm & Jimmy Member & $\begin{array}{l}\text { NERCMAR core } \\
\text { (Hunter et al., 1998) }\end{array}$ & $\begin{array}{l}\text { Massive sulphide (several } \\
\text { samples) }\end{array}$ \\
\hline \multicolumn{5}{|c|}{ South Africa } \\
\hline c. 2.64 & $\begin{array}{l}\text { Black Reef } \\
\text { Quartzite Fm, } \\
\text { Transvaal } \\
\text { Supergroup }\end{array}$ & Black Reef & $\begin{array}{l}\text { Consolidated } \\
\text { Modderfontein } \\
\text { Mine }\end{array}$ & $\begin{array}{l}\text { Fine-grained pyrite pebble } \\
\text { conglomerate with } 5 \text { vol.\% of } \\
\text { quartz granules (sample BRQ1) }\end{array}$ \\
\hline c. 2.64 & $\begin{array}{l}\text { Black Reef } \\
\text { Quartzite Fm, } \\
\text { Transvaal } \\
\text { Supergroup }\end{array}$ & Black Reef & East Geduld Mine & $\begin{array}{l}\text { Quartz pebble conglomerate } \\
\text { with } 50 \text { vol.\% rounded pyrite } \\
\text { pebbles (sample 2410) }\end{array}$ \\
\hline c. 2.72 & $\begin{array}{l}\text { Ventersdorp } \\
\text { Supergroup }\end{array}$ & $\begin{array}{l}\text { Ventersdorp } \\
\text { Contact Reef }\end{array}$ & TauTona Mine & $\begin{array}{l}\text { Quartz pebble conglomerate } \\
\text { with } 5 \text { vol.\% rounded sand- to } \\
\text { fine pebble-sized pyrite in a } \\
\text { granular quartz sand matrix } \\
\text { (samples TM1 and TM2) }\end{array}$ \\
\hline c. 2.85 & $\begin{array}{l}\text { Central Rand } \\
\text { Group, } \\
\text { Witwatersrand } \\
\text { Supergroup }\end{array}$ & Kimberley Reef & $\begin{array}{l}\text { Randfontein Estates } \\
\text { Mine }\end{array}$ & $\begin{array}{l}\text { Quartz pebble conglomerate } \\
\text { with } 50 \text { vol.\% rounded pyrite } \\
\text { pebbles (sample } 638 \text { ) }\end{array}$ \\
\hline c. 2.95 & $\begin{array}{l}\text { Mozaan Group, } \\
\text { Pongola } \\
\text { Supergroup }\end{array}$ & $\begin{array}{l}\text { Mozaan Contact } \\
\text { Reef }\end{array}$ & $\begin{array}{l}\text { Denny Dalton } \\
\text { Mine, White } \\
\text { Umfolozi Inlier }\end{array}$ & $\begin{array}{l}\text { Quartz/chert pebble/cobble } \\
\text { conglomerate with } 40 \text { vol.\% } \\
\text { rounded pyrite pebbles in a } \\
\text { granular quartz sand matrix } \\
\text { (samples PO-DD1 and -DD2) }\end{array}$ \\
\hline c. 3.08 & $\begin{array}{l}\text { Rhenosterspruit } \\
\text { Fm., Dominion } \\
\text { Group }\end{array}$ & Dominion Reef & $\begin{array}{l}\text { Dominion Reefs } \\
\text { Uranium Mine }\end{array}$ & $\begin{array}{l}\text { Quartz pebble conglomerate } \\
\text { with } 10 \text { vol.\% rounded coarse } \\
\text { sand-sized pyrite in a granular } \\
\text { quartz sand matrix (sample } \\
\text { DR2) }\end{array}$ \\
\hline
\end{tabular}


Supplementary data

Table S1. Description of pyrite texture, sampling method and analytical results. 


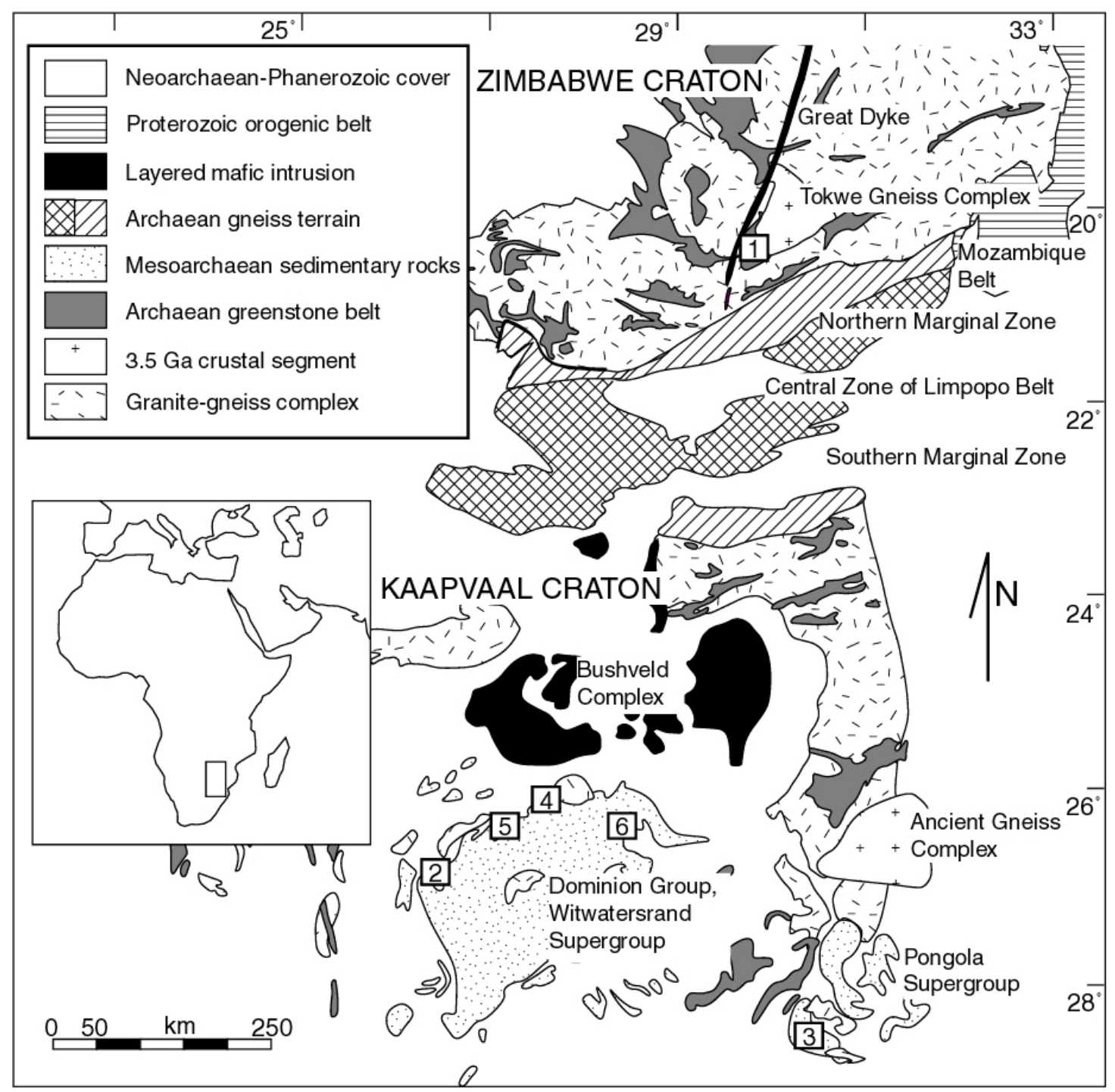

Fig. 1 


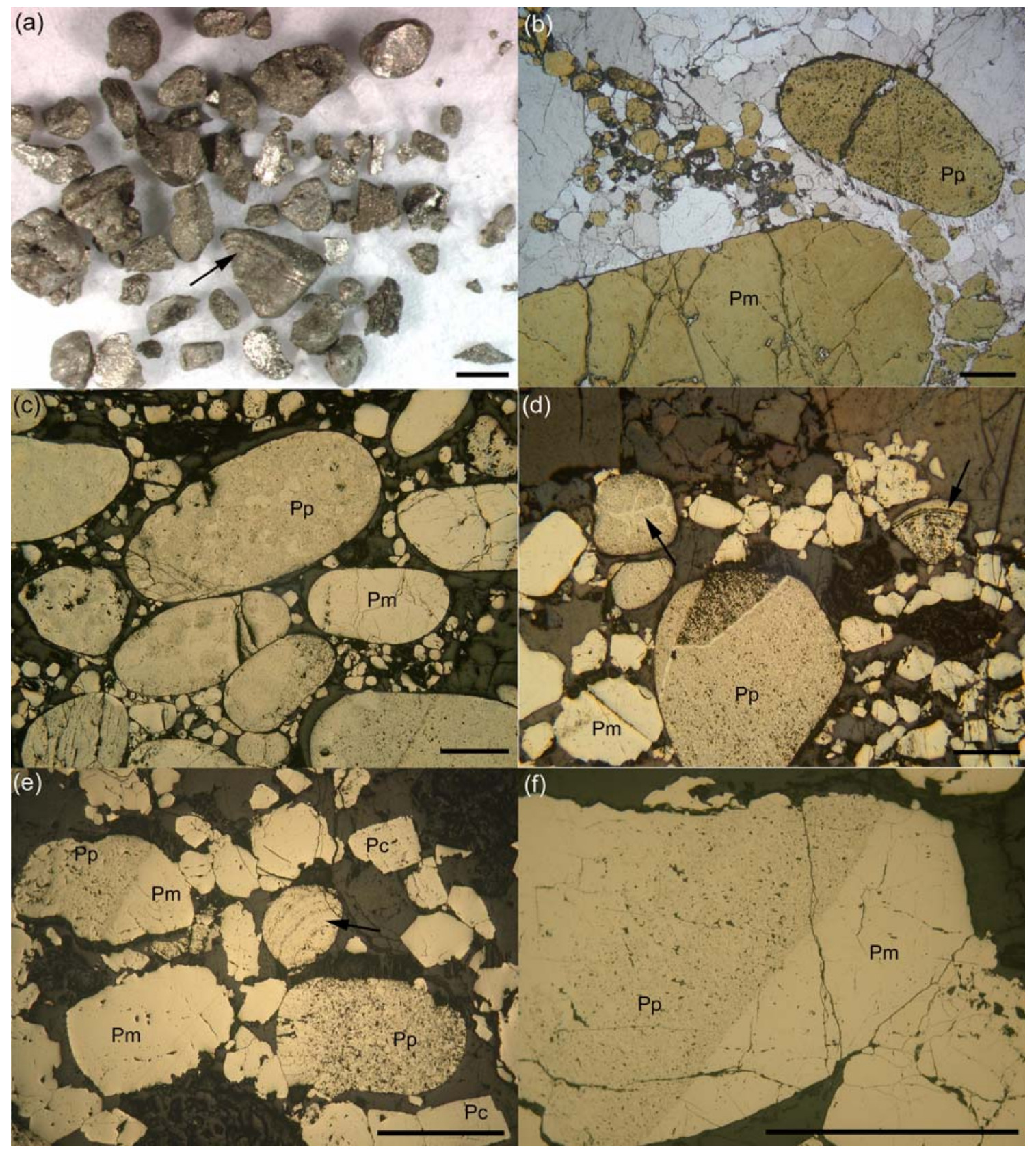

Fig. 2 

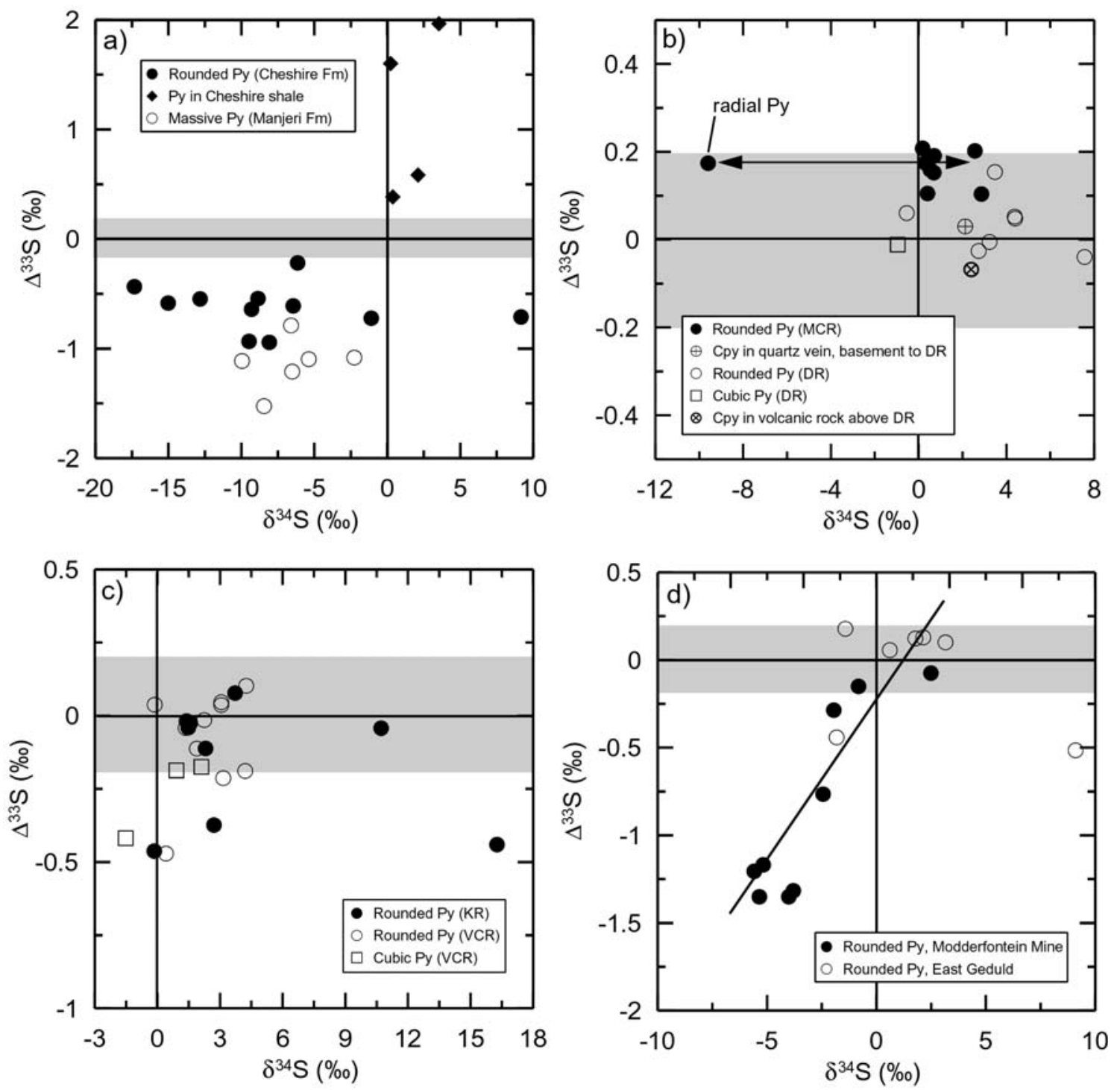

Fig. 3 


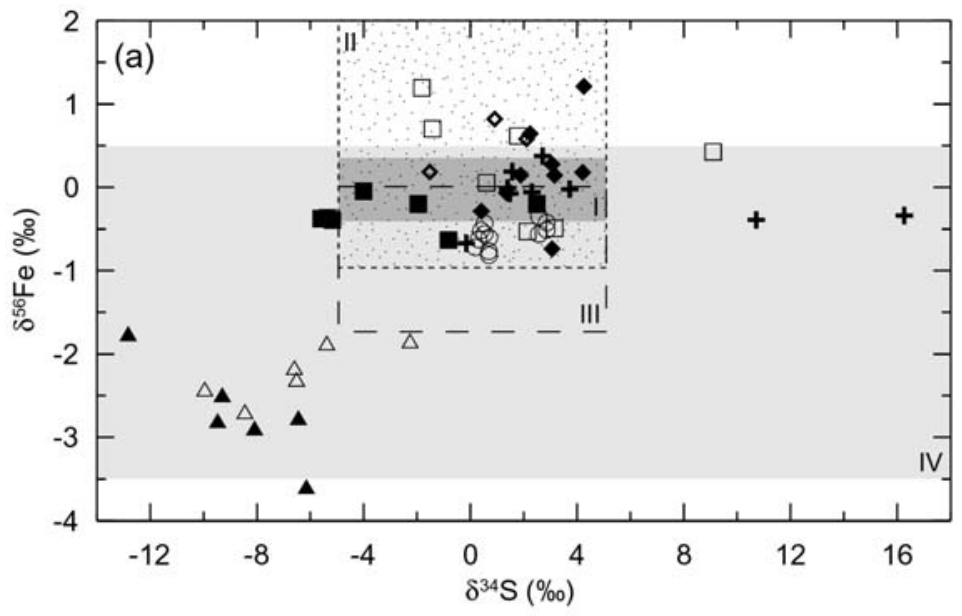

Legend

- Cheshire $\mathrm{Fm}$

$\triangle$ Manjeri Fm massive sulphides

- Black Reef (Modderfontein Mine)

$\square$ Black Reef (East Geduld Mine)

- Ventersdorp Contact Reef (cubic pyrite)

- Ventersdorp Contact Reef

+ Kimberley Reef

O Mozaan Contact Reef (all samples)

I Magmatic/ high-T hydrothermal sulphide/silicate Ii. Hydrothermal sulfidisation of Fe-oxide

I III Volcanogenic massive sulphide

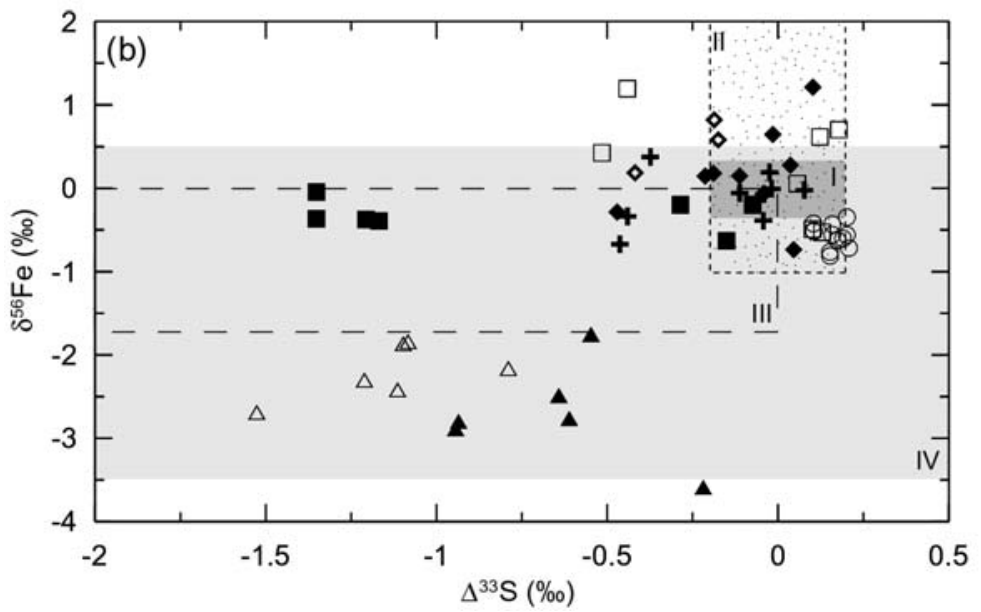

IV Sedimentary/ diagenetic/ sedex sulphide

Fig. 4 


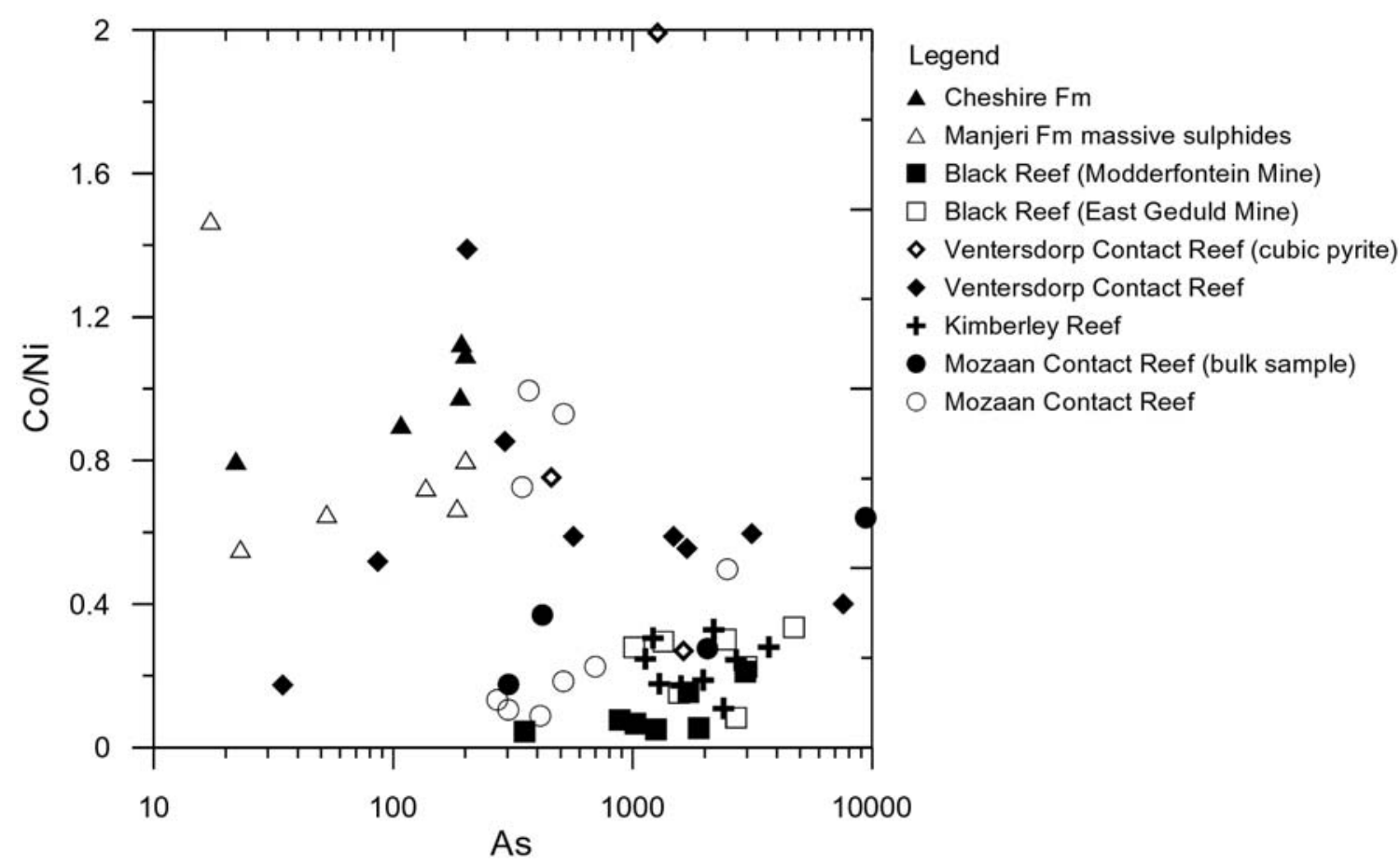

Fig. 5 